\title{
Floral biology of Impatiens trichocarpa Hook. f., (Balsaminaceae) an endemic Balsam of Western Ghats
}

\author{
S. K. Kulloli* A. K. Sreekala and A. G. Pandurangan \\ Tropical Botanic Garden and Research Institute, Palode-695 562 \\ Thiruvananthapuram, Kerala, India \\ shreekulloli@gmail.com*
}

Abstract: Floral biology of Impatiens trichocarpa, an endemic and horticulturally promising balsam from Western Ghats, has been conducted. It flowers during July to November with optimum flowering in the month of September. Anthesis occurred in the night time between 0200 to $0300 \mathrm{~h}$ and dehisced one day before anthesis. Pollen grains are spherical, light yellow in colour and $32.72 \mu \mathrm{m}$ in diameter. The maximum percentage of stigma receptivity (82\%) observed on the day of anthesis. Bees, flies and butterflies forage at the flowers; but bees serve a better pollinator. Nectar production begins soon after anthesis and continues through flower life. The seed germination was limited to $35 \%$ which may be one of the reasons for its restricted distribution.

Keywords: Anthesis, floral biology, Impatiens trichocarpa, stigma receptivity, Western Ghats.

Introduction

Impatiens Linn. spp. are stunningly handsome plants bearing a curious and variously colored flowers in the family Balsaminaceae (Sreekala et al., 2007, 2008a). These are popularly known as balsams, jewel weed, snap weed or touch-me-not (Willis, 1973). There are more than 1,000 species worldwide (Grey-Wilson, 1980; Clifton, 2000; Caris et al., 2006), most of which occurs in montane in subtropical regions from India to south-east Asia (Tian et al., 2004). Only a few species are found in temperate zones (Grey-Wilson, 1985). The species found in Sino-Himalayan region are conspicuously diversified (Hooker, 1904-1906, 1908, 1910-1911). It is essentially a sub-cosmopolitan and phytogeographically a unique genus which has its greatest development in the Indian region (Bhaskar, 1981).

In India, the concentration of species of Impatiens is remarkably local and occurs in three well defined regions viz., Western Himalayas, hills of north Eastern States and Western Ghats. Two hundred and six species have been found in India (Vivekananthan et al., 1997; Vishwanathan et al., 2003; Bhasker, 2006; Sreekala et al., 2008) which represents approximately $20 \%$ of Impatiens species worldwide. Most are found in Western Ghats and Western Himalayas and are endemic to the country or are restricted to a number of provinces. The geographical distribution of Impatiens is very localized and endemic. Out of 92 Impatiens species occur in the peninsular India, more than 86 are endemic and confined to the Western Ghats (Nair, 1991). Due to their restricted distribution and island biogeography, nearly 30 species are already in threatened category including Impatiens trichocarpa with uncertain future (Vajravelu \& Daniel, 1983; Pandurangan \& Pushpangadan, 1997).

Though the ideal climatic conditions prevailing in the Western Ghats region provide suitable habitat for the Impatiens, their populations are rapidly declining due to various factors such as fragmentation of populations, narrow environmental niche, habitat degradation, lack of specific pollinating agents, poor seed germination, anthropogenic pressures, reproductive constraints etc. Despite the abundance of Impatiens species in India, studies on floral biology have not been reported. The floral biology is prerequisite in plant breeding and obtaining better yields of plants. In this context as a preliminary step in the breeding programme, a detailed investigation on the floral biology of Impatiens trichocarpa endemic to Western Ghats has been carried out. The main objective of the study was to find out causes of rarity and endemism in the natural condition and also light on different methods of pollination.

\section{Materials and Methods}

Impatiens trichocarpa was collected from Mukurti of Nilgiri district, Tamil Nadu, India. The plants were multiplied and grown in the field garden of Tropical Botanic Garden and Research Institute, Palode, Trivandrum for detailed investigation on floral biology. The structural morphology of the flower was studied in detail using a dissection microscope. An extensive field exploration has been done in the Nilgiris to find out the flowering period and floral nature of the candidate species. Flower colour, odour and nectar were observed visually. Anthesis and anther dehiscence were observed using a fluorescent lamp at night and a hand lens following the method of Reddi and Janaki Bai (1981), Mathur and Mohan Ram (1986). The pollen production per flower was estimated using the haemocytometer method and calculated using the following formula:

$\mathrm{N}=\frac{\mathrm{a} \times \mathrm{v} \times 10^{4}}{\mathrm{n}}$, where

$\mathrm{N}=$ Number of pollen grains/flower

$a=$ Mean No: pollen grains counted/corner square

$v=$ Volume of suspension made with anther

$\mathrm{n}=$ No: anthers with which the suspension made up of

The pollen ovule ratio $(\mathrm{P} / \mathrm{O})$ was calculated following Cruden's (1977) method:

Pollen count/anther $x$ no. of anthers/flower

$\mathrm{P} / \mathrm{O}=\frac{\text { No. of ovules/flower }}{\mathrm{P}}$
Research article

CIndian Society for Education and Environment (iSee)
"An endemic balsam from India" http://www.indjst.org
Kulloli et al. Indian J.Sci.Technol. 
Pollen fertility and viability was assessed by the method of Shivanna \& Rangaswamy (1992). acetocarmine glycerin staining techniques and FCR Receptivity of stigmas at different times of flower
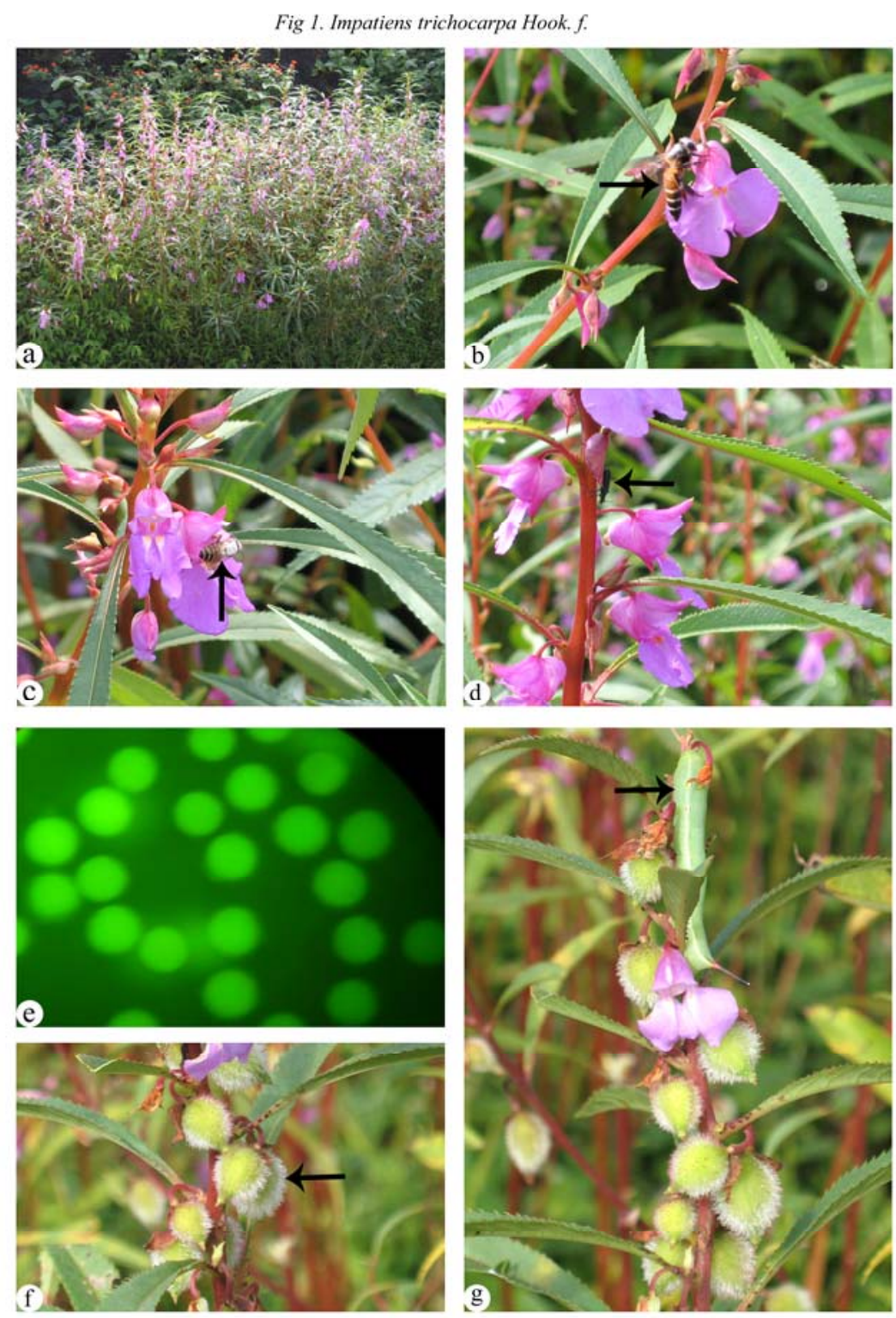

a- Habit; b-Apis dorsata foraging the nectar by puncturing the spur; $c$-Apis indica collecting the ectar; $d$ - beetle landing on flower; $e$ - Pollen viability by FCR test; $f$ - Hairy fruiting branch through xenogamy; g-Caterpillar infestation (green caterpillar landing on the flower)

test respectively suggested by Shivanna and Rangaswamy (1992) and Dafni et al. (2005). To have a knowledge about in vitro pollen germination; freshly collected and uncontaminated pollens from immediately dehisced anther was put onto to the sucrose solution of different concentrations $(5,10,15$, $20 \%$ ) and Brewbakers medium. The prepared slides were kept within petridishes lined with moist filter paper for incubation. After the stipulated period, the percentage of pollen germination and pollen tube elongation was noticed under light microscope (Lieca DME, Germany) and calculations were made following opening was measured following in vivo pollen germination according to the standard method suggested by Joshirao \& Saoji (1989). Two types of nectar measurements were made, one immediately after anthesis and another two hours after anthesis. Micropipettes were used for this purpose (Drumond $5 \mu \mathrm{l}$ USA). Nectar sugar concentrations were recorded using a hand refractometer (Erma, Japan).

Tests for autogamy, geitonogamy, and xenogamy were conducted on 50 flowers distributed in 10 plants for each mode of reproduction and fruit set recorded. During all the visits made to the plants under observation, representative samples of flower visitors were collected using insect net and later identified by our research group and standard insect taxonomy manual. Further, the type of food collected by different visitors, foraging period was recorded by close observation.

Result and Discussion:

The plant set full vegetative growth following monsoonal rains in June and start flowering during late July (Fig. 1a). Flowering is synchronous in the habitat. Impatiens tomentosa, I. oppositifolia and I. chinensis are the other Impatiens $\mathrm{sp}$. grows and flower in association with Impatiens trichocarpa. It is $20-60 \mathrm{~cm}$ high with sparingly branched stem. Flowers are pink in coloured and solitary or binate at axillary cyme. The spur is shorter than lip, robust and incurved (Fig. 1b). Capsules are ellipsoid and turgid in nature with tomentose hairs (Fig. 1f).

It starts flowering in the month of July and extended up to January (Table 1). The flower buds take 8-12 days from initiation to full bloom. The plants were in flower for a total of 180 days in a year. The average life span of each flower is 2-3 days. Flower starts opening after mid-night around $0200-0300 \mathrm{~h}$ and remain fresh till the morning. The anther dehiscence takes place one day before flower opening, which confirmed protandrous condition of the flower. Sreekala et al. (2007, 2008) also reported parallel findings in Impatiens campanulata and Impatiens henslowiana respectively. Bhaskar and Razi (1974) had reported that majority of wild balsams grown in the high altitude are night blooming and have wide range of timing with regard to anthesis and pollen germination. Study of
Research article

CIndian Society for Education and Environment (iSee)
"An endemic balsam from India" http://www.indjst.org
Kulloli et al. Indian J.Sci.Technol. 


\section{Table 1. Floral characters of Impatiens trichocarpa}

\begin{tabular}{|c|c|}
\hline Floral Characters & Observations \\
\hline Inflorescence & Axillary raceme \\
\hline Flower type & $\begin{array}{l}\text { Hermaphrodite, } \\
\text { zygomorphic }\end{array}$ \\
\hline Flower colour & Pale pink \\
\hline Flowering period & July-January \\
\hline Odour & Mild \\
\hline Nectar & Present $2.5 \mu \mathrm{l}$ \\
\hline Flower opening time & 0200-0300h \\
\hline No. of anthers/flower & 5 \\
\hline Anther dehiscence time & $\begin{array}{c}\text { 0230-0330h(One day } \\
\text { before anthesis) }\end{array}$ \\
\hline Anther dehiscence mode & Apical slit \\
\hline Average no. of pollens/anther & $7656 \pm 30$ \\
\hline Mean no. of pollen grains/flower & $38,280 \pm 50$ \\
\hline Mean no. of ovules/flower & 20 \\
\hline Pollen-ovule ratio & 1914:1 \\
\hline Pollen type & 3-colporate \\
\hline Pollen size & $\pm 32.72 \mu \mathrm{m}$ \\
\hline Pollen shape & Spherical \\
\hline Ovary type & Bicarpellary syncarpous \\
\hline Stigma type & Wet and non-papillate \\
\hline Stigma receptivity \% & $82 \%$ \\
\hline
\end{tabular}

anthesis and anther dehiscence is vital for subsequent dispersal of pollen grains into the atmosphere. The mean number of pollen grains and ovules per flower was 38,280 and 20 respectively. Therefore, the pollenovule ratio was calculated as 1914:1. This higher pollen-ovule ratio suggests outbreeding nature of the species. Pollen productivity depends on anther length, pollen grain size and mode of anther dehiscence (Reddi \& Reddi, 1986; Linskens, 1992). The pollen out put is related to fruit and seed setting.

In Impatiens trichocarpa pollen grains are spherical and an average of $32.72 \mu \mathrm{m}$ in diameter (Fig. 1e). The acetocarmine glycerin technique revealed that $88 \%$ of pollen grains were fertile. Pollen viability by FCR test confirmed that $90 \%$ pollen grains were viable on the day of anthesis (Fig. 1e). Study on in vitro pollen germination using different medium revealed that $75 \%$ of pollen grains were germinated and achieved tube length of $685 \mu \mathrm{m}$ in $5 \%$ sucrose medium. Germination potential was significantly low in higher concentrations of sucrose medium. Pollen viability is maximum on the day of anthesis and gradually decreased on successive days after anthesis. These observations are similar to that of Impatiens reptans in china (Tian et al., 2004) and I. coelotropis in India (Sreekala et al., 2008). Sucrose is the best carbohydrate source for pollen germination having its function in maintaining osmotic pressure of the medium and acting as a substrate for pollen metabolism (Johri \& Vasil, 1961; Shivanna \& Johri, 1989). In the present investigation $5 \%$ sucrose medium is the most suitable medium for pollen

Research article

CIndian Society for Education and Environment (iSee) germination in vitro.

The stigma is wet and non-papillate type. Stigmas were more receptive, i.e. $82 \%$ on the first day of anthesis, showing $45 \%$ in vivo pollen germination along with $872 \mu \mathrm{m}$ long pollen tubes on stigmatic surface, but the receptivity percentage and in vivo pollen germination percentage gradually decreased in successive days after anthesis (Table 2). Receptivity of stigma is a critical factor for successful completion of post-pollination events. Usually it becomes maximum soon after anthesis but varies from species to species. Pollen fertility and pollen tube growth on the stigma surface and the style are very sensitive to temperature charges. After being successfully placed on stigma surface the pollen undergoes hydration. Subsequent to hydration, pollen wall proteins are release on the stigmatic surface (Heslop-Harisson et al., 1975) and the stigmatic pellicle acts as a receptor of pollen wall proteins (Joshirao \& Saoji, 1989). Thus the pollen grains are recognized and begin to germinate on the stigmatic surface. The nectar secretion begins an hour before anthesis and continues even after anthesis for ca $3 \mathrm{~h}$. The fully open flower holds $2.5-3 \mu \mathrm{l} \pm 0.52$ of nectar. A sugar concentration of nectar at anthesis is $15 \%$ and later it varies between 16 and $20 \%$, probably due to water evaporation during bright sunlight hours.

In Impatiens trichocarpa the flower open in early morning between $0200-0300 \mathrm{~h}$ therefore, the major pollinators are honeybees, butterflies, pollen bees, flies and beetles (Table 3). Honey bees (Apis dorsata and Apis indica) foraged during daytime for both nectar and pollen (Fig. 1b, c). While Trigona iridipennis exclusively concentrated on pollen robbing. Flies (Chrysomya sp.) and butterflies (Pachliopta aristolochiae and Euploea core) foraged nectar only during their visit to individual flowers (Table 3). Beetles intermittently, are also visited the flowers for nectar as well as pollen (Fig.1d). The honeybees began foraging from $0600 \mathrm{~h}$ to $1500 \mathrm{~h}$. Trigona iridipennis forage during $0700 \mathrm{~h}-1100 \mathrm{~h}$ and butterflies during $0700-1600 \mathrm{~h}$. The pollen collecting bees usually landed on the wing petal and gathers pollen from the anthers. Sometime they landed directly on anther lobes and foraged the pollens. The bees directly landed on the coherent anther lobe and effected pollination. In general flower visitors were low in density and of the total visits, bee made $55 \%$,

Table 3. List of insects and forage collected by them in I. trichocarpa

\begin{tabular}{|c|c|c|c|c|c|}
\hline Order & Family & Genus & pecies & Foraging & \\
\hline & & & & nature & time \\
\hline Hymenoptera & Apidae & Apis & florea & $\mathrm{N}^{*}$ and $\mathrm{P}^{*}$ & Day \\
\hline & & Apis & indica & $\mathrm{N}$ and $\mathrm{P}$ & Day \\
\hline & & Apis & dorsata & $P$ & Day \\
\hline & & Trigona & iridipennis & $\mathrm{N}$ & Day \\
\hline Diptera & Calliphoridae & Chrysomya & & $\mathrm{N}$ & Day \\
\hline Lepidoptera & Papiliodae & Pachliopta & aristolochiae & $\mathrm{N}$ & Day \\
\hline & Danaidae & Euploea & core & $\mathrm{N}$ & Day \\
\hline
\end{tabular}

$N^{*}-$ Nectar, $P^{*}$ - Pollen

"An endemic balsam from India" http://www.indjst.org
Kulloli et al. Indian J.Sci.Technol. 
Table 2. In vivo pollen germination of Impatiens trichocarpa

\begin{tabular}{|l|l|l|l|l|}
\hline \multirow{2}{*}{ No Observations/estimation } & \multicolumn{4}{|c|}{ Period after flower opening } \\
\cline { 2 - 5 } & \multicolumn{4}{|c|}{ I day II day Il day Drooping } \\
\hline stigmas observed (total) & 10 & 10 & 10 & 10 \\
No. of stigmas showing germination & 8.2 & 5 & 2 & 0 \\
\% of stigma receptivity & 82 & 50 & 20 & 0 \\
pollen retained on stigma (total) & 42,110 & 22,200 & 1280 & 10 \\
Mean no. of germinated pollen & 18,949 & 6260 & 115 & 0 \\
\% of pollen germination & 45 & 28.1 & 8.9 & 0 \\
Pollen tube length $(\mu \mathrm{m})$ & 872 & 322 & 92 & 0 \\
\hline
\end{tabular}

Vol.2 No 2 (Feb. 2009) butterflies $25 \%$ and flies $20 \%$. The frequency of bee visit is more than the other visitors. Therefore, honeybees are the major pollinators of Impatiens trichocarpa. It is well known that the flowers of Impatiens have enormous diversity and different pollinators. In tropical regions of Indian subcontinent the Impatiens are pollinated by honeybees, butterflies and moths (Sreekala et al., 2007, 2008, 2008a), whereas in subtropical regions of Africa the Impatiens are pollinated by humming birds as well as by insects (Grey-Wilson, 1980). In temperate zones, pollinators are bumble-bees and humming birds only (Rust, 1977, 1979; Heinrich, 1979; Kato et al., 1989). Hence, in different climatic regions, species of pollinators vary with respect to geographic set-up.

In natural pollination only $45 \%$ fruit set was observed. The fruit set was not observed in autogamy (selfing within the individual flower). However $55 \%$ fruit set was observed in geitonogamy (selfing between the flowers) and $72 \%$ in xenogamy (allogamy). Artificial cross-pollination especially xenogamy produced more fruits and seeds than the natural pollination. Therefore the percentage of fruit set in manually pollinated flower is higher than that of resulting from open pollination, conforming that pollination is a limitation for fruit set in the Impatiens trichocarpa. This strongly indicates that some external agents are required for successful pollination. The species is poorly distributed in the wild mainly because of habitat loss, narrow environmental niche, fragmentation population, lack of specific pollinating agent and their own reproductive constraints, which may be one of the reasons for poor distribution in the wild conditions. Also natural fruit set rate is very low due to inadequacy of pollinators as well as caterpillar infestation which causes early chomp of flowers (Fig. 1g). All these causal factors either alone or in combination with others are responsible for its limited distribution of Impatiens trichocarpa in the wild.

\section{Acknowledgements}

We thank Dr. Seeni, Director I/C TBGRI, Palode, Trivandrum for the facilities.

References

1. Bhasker V (1981) The genus Impatiens L. in South India: Endemism and Affinities. Ind. For.107 (6), 368-376.
2. Bhasker V and Razi BA (1974) Nocturnal pollen germination in Impatiens (Balsaminaceae). Curr. Sci. 43 (19), 626-628.

3. Bhasker V (2006) Impatiens clavata Bhasker sp. nov. - A new scapigerous balsam (Balsaminaceae) from Bisle Ghat, Western Ghats, South India. Curr. Sci. 91 (9): 1138-1140.

4. Caris PL, Koen PG, Steven BT and Erick FS (2006) Floral development in three species of Impatiens (Balsaminaceae). Am. J. Bot. 93(1), 1-14.

5. Clifton R (2000) Geraniales species checklist series Vol. 6, Geraniaceae, Bentham and Hooker tribe VIII Balsaminaceae. Dover: The Geraniaceae Group.

6. Cruden RW (1977) Pollen-ovule ratios: a conservative indicator of breeding system in flowering plants. Evolution. 31, 32-46.

7. Dafni A, Kevan PG and Husband BC (2005) Practical Pollination Biology. Enviroquest. Ltd. Cambridge, Ontario, Canada.

8. Grey-Wilson C (1980) Impatiens of Africa; Morphology, pollination and pollinators, Ecology, Phytogeography, Hybridization, Keys and a Systematics of all African species with a note on collecting and cultivation. A. A. Balkema, Rotterdam, Netherlands.

9. Grey-Wilson C (1985) Balsaminaceae. In: A revised handbook of the flora of Ceylon. Dassanayaka, M. D and Fosberg, F. R. (ed.). Amerind publ. Co. Pvt. Ltd., New Delhi. pp: 76-120.

10. Heinrich B (1979) Resource heterogeneity and patterns in foraging bumble-bees. Oecologia 40, 235-245.

11. Heslop-Harrison J, Heslop-Harrioson $Y$ and Barber J (1975) The stigma surface in incompatibility response. Proceedings of Royal Society, London. Series B. 187, 287-297.

12. Hooker JD (1904-1906) An epitome of the British Indian species of Impatiens. Records of the botanical survey of India. 4, 1-58.

13. Hooker JD (1908) Impatiens In: Hooker's Icones Plantarum, $4^{\text {th }}$ series 9. London. pp. 2851-2875.

14. Hooker JD (1910-1911) Impatiens In: Hooker's Icones Plantarum, $4^{\text {th }}$ series 10 . London. pp: 29012975.

15. Johri BM and Vasil IK (1961) Physiology of pollen. Bot.Rev. 27, 325-381.

16. Joshirao JA and Saoji AA (1989) Studies on in vivo germination of pollen of some alkaloid bearing plants. J. Palynology. 25, 45-50.

17. Kato $M$, Itino I, Hotta $M$, Abbas I and Okada H (1989) Flower visitors of 32 plants species in west Sumatra. Occasional papers of the Kagoshima
Research article

CIndian Society for Education and Environment (iSee)
"An endemic balsam from India" http://www.indjst.org
Kulloli et al. Indian J.Sci.Technol. 
University Research center for South Pacific. 16, 15-31.

18. Linskens HF (1992) In: Sexual plant reproduction. Cresti, M and Tezzi, A. (ed.) Springer-Verlog, Berlin). pp: 203-218.

19. Mathur G and Mohan Ram HY (1986) Floral biology and pollination of Lantana camara. Phytomorphology 36, 79-100.

20. Nair NC (1991) Endemism on the Western Ghats with special reference to Impatiens L. Proceedings of the symposium on rare, endangered and endemic plants of Western Ghats, Kerala forest Dept. (Wildlife Wing) Thiruvanathapuram spl. Publ. No III, 93-102.

21. Pandurangan AG and Pushpangadan $P$ (1997) Causes of rarity and extinction of species in plants with reference to Western Ghats. Frontiers in Plant Science. Om Sai Graphics, Hyderabad.

22. Reddi CS and Janaki Bai AJ (1981) Floral biology of Mimuseps elengi. J. Bombay Nat. Hist. Soc. 77, 471-475.

23. Reddi CS and Reddi NS (1986) Pollen production in some anemophilous angiosperms. Grana 25, 55-61.

24. Rust RW (1977) Pollination in Impatiens capensis and Impatiens pallida (Balsaminaceae). Bull. Torrey Bot. Club. 104, 361-367.

25. Rust RW (1979) Pollination in Impatiens capensis: pollinators and nectar robbers. J. Kanasas Entom. Soc. 52, 297-308.

26. Shivanna KR and Johri BM (1985) The Angiosperm pollen-structure and function. Wiley Eastern Ltd. New Delhi.

27. Shivanna KR and Rangaswamy NS (1992) Pollen biology- a laboratory manual. Narosa Publ. House, New Delhi. pp: 35-36.

28. Sreekala AK, Pandurangan AG, Ramasubbu $R$ and Kulloli SK (2008) Pollination biology of Impatiens campanulata Wight. Advances Pollen Spore Res. 26, 9-19.

29. Sreekala AK, Pandurangan AG, Ramasubbu $R$ and Kulloli SK (2008a) Reproductive biology of Impatiens coelotropis Fischer a critically endangered balsam from the southern Western Ghats. Curr. Sci. 95 (3), 386-388.

30. Sreekala AK, Ramasubbu R, Kulloli SK and Pandurangan AG (2007) Pollination biology of Impatiens henslowiana Arn. (Balsaminaceae). Ind. J. Bot. Res. 3(1), 165-171.

31. Tian J, Keming Liu and Guangwan Hu (2004) Pollination ecology and pollination system of Impatiens reptans (Balsaminaceae) endemic to China. Ann. Bot. 93, 167-175.

32. Vajravelu E and Daniel P (1983) Materials for a catalogue of threatened plants of India Botanical Survey of India, Calcutta.
33. Vishwanathan MB and Manikandan U (2003) A new species of Balsaminaceae, Impatiens tirune/velica, from Peninsular India. Bull. Bot. Surv. India. 45(1-4), 189-194.

34. Vivekananthan K, Rathakrishnan NC, Swaminathan MS and Ghara LK (1997) Balsaminaceae. In: Flora of India (MaphighiaceaeDichapetalaceae). Hajra P. K., Nair V. J and Daniel P. (ed.) Botanical Survey of India. Calcutta. 4, 95229.

35. Willis JS (1973) A Dictionary of Flowering Plants and Ferns. $\left(8^{\text {th }}\right.$ revised edition by Airy Shaw, H. K) Cambridge University Press, Cambridge. pp:591592.

36. Yuan YM, Song YI, Geuten Koen EE, Rahelivololona S, Wohlhauser E, Fischer S, Smets and Kupfer P (2004) Phylogeny and Biogeography of Balsaminaceae inferred from ITS sequens data. Taxon 53, 391-403. 